\title{
ACKR2 wt Allele
}

National Cancer Institute

\section{Source}

National Cancer Institute. ACKR2 wt Allele. NCI Thesaurus. Code C51317.

Human ACKR2 wild-type allele is located in the vicinity of 3p21.3 and is approximately 58 $\mathrm{kb}$ in length. This allele, which encodes atypical chemokine receptor 2 protein, is involved in the recruitment of effector immune cells to sites of inflammation. The allele also plays a role in chemokine-driven leukocytes recirculation. Variant alleles have been implicated in chemokine effects relating to the development and growth of vascular tumors. 